DANIELA KOLTOVSKA NEČOSKA, M.Sc.

E-mail: daniela.koltovska@uklo.edu.mk

KRISTI M. BOMBOL, Ph. D.

E-mail: kristi.bombol@uklo.edu.mk

University "St. Kliment Ohridski",

Faculty of Technical Sciences

POB 99, 7000 Bitola, Republic of Macedonia
Traffic Management

Preliminary Communication

Accepted: Feb. 17, 1009

Approved: Oct. 22, 2009

\title{
THE IMPACT OF DETECTOR PLACEMENT ON SIGNALIZED INTERSECTION PERFORMANCE
}

\begin{abstract}
Despite the flow fluctuations and increased traffic demand in the Macedonian cities over the last fifteen years, the Republic of Macedonia is one of those countries which still employ only the traditional systems of traffic management and control. Those are fixed control systems that certainly cause problems such as increased travel times and travel expenses as well as environmental degradation. A general call for "...something has to be done..." becomes obvious. The best practices have shown that this can be realized through unconventional solutions i.e. by means of responsive traffic management. A very reasonable example of such a system is the vehicle actuated control system that we have found to be quite challenging to do our research. Thus, we set up two folded research issues in front of us. The first one was to scientifically prove that vehicle actuated signal control can really be a reasonable substitute for a fixed time signal control, which will enhance the overall signalized intersection performance provided the timing parameters and the detector placement ril properly designed. The second one was to indicate that such an advanced control system is feasible and sustainable for Macedonian cities. This paper focuses on the first research issue only.

For this purpose, a semi-actuated signal control strategy on an appropriately chosen signalized intersection was designed. The primary objective was to determine the way in which the inductive loop detector placement from the STOP line affects the overall intersection performance. To meet the goal, two scenarios were designed: 1. Detector placement at the STOP line, and 2. Detector placement at 8 metres behind the STOP line. Emphasis was placed on the semi-actuated signal control algorithm design. The designed algorithm was then applied in the net of VISSIM in order to simulate the semi-actuated signal control process. Performance comparison analysis with the formerly pre-timed signal control strategy followed. It was concluded that the overall intersection performance could be improved both by adequate inductive loop detector placement and by interaction with signal parameters. Hence, the placement distances would have to be considered under the limitation conditions only.
\end{abstract}

\section{KEYWORDS}

signalized intersection, vehicle actuated control, semi-actuated control, inductive loop detectors, simulation, delays, level of service

\section{INTRODUCTION}

In the last twenty years a lot of work has been put into the development of advanced traffic management and control systems. In Europe and the USA there is a tendency towards the design and implementation of traffic management systems, which will enable harmonization of the traffic process in space and time in order to increase traffic network capacity as well as to enhance traffic safety and provide "righteous" distribution of the green time for all the users. Experiences have shown that this can be realized through unconventional solutions i. e. by means of responsive traffic management. For more than two decades the actuated control systems have been functioning and undergoing improvement and development of the technologies. A large number of algorithms and techniques of actuated control have been applied. Among the most known signal control strategies are the British MOVA (Microprocessor Optimized Vehicle Actuated) and the Swedish LHOVRA (English translation of the acronym - Truck/bus and platoon priority, Main road priority, Incident reduction, Variable amber time, Red-driving control, All red turning).

Despite the flow fluctuations and increased traffic demand in the Macedonian cities in the last fifteen years, the Republic of Macedonia is one of those countries which still employ only the traditional systems of traffic management and control. Those are fixed control systems which burden the network with problems such as increased travel times and travel expenses as well as environmental degradation ${ }^{1}$.

A general something-has-to-be-done call becomes obvious. The best practices have shown that this can be realized through unconventional solutions i. e. by means of responsive traffic management. Although artificial intelligence and its application in traffic management and control systems have already entered the stage, it was concluded that at this point of identified problems one should start from a very reasonable signal control system. 
The motive behind the research undertaken was two folded. The first research issue was to scientifically prove that vehicle actuated signal control can really be a reasonable substitute for a fixed time signal control, which will enhance the overall signalized intersection performance when the timing parameters and the detector placement distances are designed properly. The second one was to indicate that such an advanced control system is feasible and sustainable for the Macedonian cities. This paper focuses on the first research issue only.

For this purpose, a semi-actuated signal control strategy on an appropriately chosen signalized intersection was designed. Since the appropriate detectors placement is considered to be one of the significant parameters of the vehicle actuated control operations, this paper deals with the impact of the detector placement on the overall intersection performance expressed by the delays and the level of service achieved.

During the research, the methods of analysis and synthesis, mathematical-empirical methods, micro simulation (simulation package VISSIM and the program module VAP) were used.

\section{ON THE CONCEPT OF VEHICLE ACTUATED CONTROL}

Bank (TFK, 1982) has divided the methods to operate the individual signalized intersections as follows:

- Fixed time signal control (FT): Predetermined, fixed signal timing calculated to minimize overall intersection delay for the traffic demand. Separate time plans can be developed for different periods during the day.
- Vehicle actuated control (VA): Variable green time allocations and cycle time based on detection of the traffic demand in the signalized approaches or groups of lanes. The decision to extend green light or not is based solely on the conditions for the actual approaches or signal groups served by the ongoing green.

- Self-optimized real-time control: Variable green time allocation and cycle time based on real-time optimization of traffic performance with regard to the conditions for all the signalized approaches in the intersection.

There are three basic types of vehicle actuated control, each with controllers that are somewhat different in their design ${ }^{2}$ :

1. Semi-actuated Control: Includes detection only on minor side-street approaches to the intersection. The green remains on the main street until "call" for service on the side-street is registered. This type of control is frequently used when side-street traffic is relatively light, but traffic signals are required to periodically interrupt the main flow to allow side-street vehicles to safely cross (the case in our research).

2. Full-actuated Control: All approaches are with detectors and with sequenced phases according to "calls" for service. This type of control is common at busy, isolated intersections, where daily demand fluctuations would cause any fixed time control to be inefficient.

3. Volume-density Control: It is basically the same as full-actuated control with additional demand responsive features.

The actuated control uses the information on current demands obtained from detectors within the in-

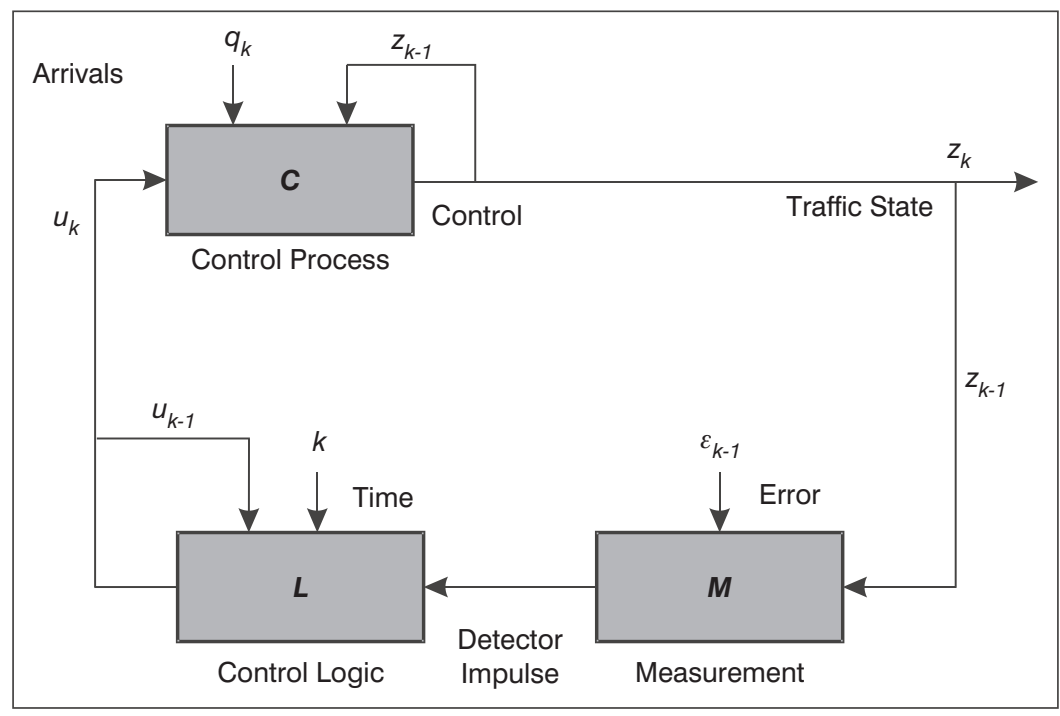

Figure 1 - Process of actuated traffic control

Source: Luttenen T. R., Nevala. R., Capacity and Level of Service of Finnish signalized Intersections, Finnra Reports 25/2002, Helsinki, p. 35 
tersection. The actuated controllers can be programmed to provide variable phase order, alternating green times for each phase, alternating length of the cycle caused by the alternating green times.

The signal control can be expressed as

$u_{k}=L\left(u_{k-1}, \mu_{k-1}, k\right)$,

where $L$ is the control logic, $u_{k-1}$ is the management signal in the previous basic interval $k-1, \mu_{k-1}$. is the detective impulses in the previous basic interval $k-1$, and $k$ is the basic interval. 1.

The process of actuated control is shown in Figure

The vast majority of actuated signal installations use inductive loops for detection purposes. The actuated controller can change the length of the green time, which in turn reduces the increase of waiting queues. Thereby, the importance of the appropriate placement of detectors is obvious. Unfortunately, in many installations, the placement of the detectors has been treated as a secondary concern even though vast amounts of money have been approved for the selection of the controller unit.

One of the principal parameters affecting some of the timing parameters (minimum green time, time extension unit, maximum green, the yellow and the all red time) is the placement of the detector or how far it is placed from the STOP line.

\subsection{Strategies of detectors placement}

Experiences show that detector placement strategies vary, but generally speaking, the following analysis is needed: a) placement distance, b) number of detectors c) type of detectors.

The most common form of detection is the Point Detection. It is commonly implemented with a single short inductive loop. In such scheme, a single detector is placed for each approach lane to actuate the controller. The detector gathers information as to whether a vehicle has passed over the detector.

Another strategy is the so called Area Detection. It is provided by using a long inductive loop or series of point detections.

However, the analysis of different signal control strategies cannot allow the conclusion that a larger number of detectors installed would provide a more efficient traffic process.

For the purpose of this research the point detection strategy has been applied. In our case the inductive loop passage detectors have been installed only on the minor intersection lane approaches, with dimensions of $1.1 \times 2.0 \mathrm{~m}$.

\section{OPERATIONAL ANALYSIS OF THE INTERSECTION PERFORMANCE}

\subsection{Data collection and analysis}

A survey of the intersection Partizanska St. - Toso Daskalo St. - Strcin St. in the City of Bitola was carried out (Figure 2).

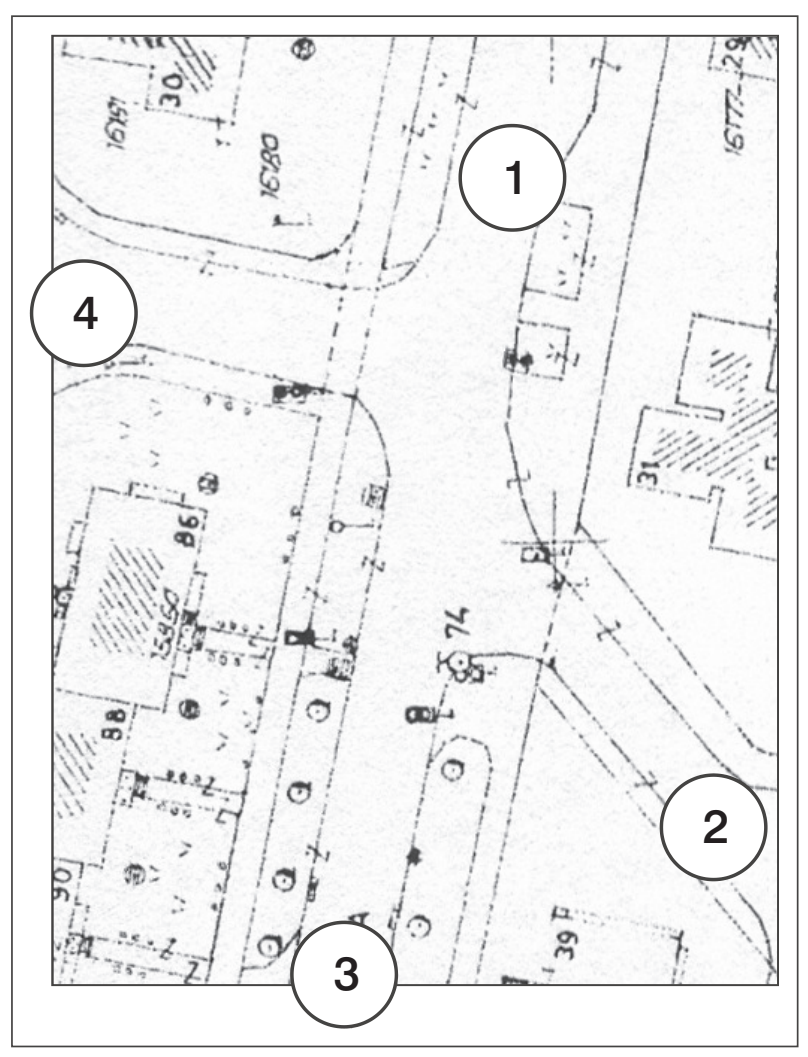

Figure 2 - Location of intersection approaches

In order to make intersection performance analysis, the following data were necessary:

1) intersection characteristics - type of area, number of lanes, lane width, grade (presented in Table 1),

2) traffic conditions (traffic flows, $\%$ of $\mathrm{HGV}$ and BUS, the peak hour...),

3) traffic signal parameters (cycle length, green time, yellow time).

The traffic data were collected on the basis of sixteen hours counting (from 6 a. m. till 10 p. m.) in 15 -minute intervals on 4 counting points (approaches 1, 2, 3 and 4). The data processing showed that the peak hour was from $3 \mathrm{p}$. m. to $4 \mathrm{p}$. $\mathrm{m}$. The peak hour demand flows in vehicles per hour are depicted in Figure 3.

The misbalance of the traffic volumes is evident (major flow/minor flow - East, West/North, and South). In certain day periods, the ratio major/minor flow is larger than 3:1, particularly distinctive is Approach 1/Approach 2 ratio (Figures 4 and 5). The flow 
Table 1 - Intersection field data

\begin{tabular}{|c|c|c|}
\hline Approaches & Parameters & Data \\
\hline \multirow{7}{*}{ Approach 1 - E } & Area Type & Other \\
\hline & \multirow{2}{*}{ No. of lanes } & 2 entry lanes \\
\hline & & 1 exit lane \\
\hline & Lane width & $3.00 \mathrm{~m}$ \\
\hline & Grade & $0 \%$ \\
\hline & Separate left/right turn lanes & Separate left turn lane \\
\hline & Parking provisions & None \\
\hline \multirow{6}{*}{ Approach 2 - S } & \multirow{2}{*}{ No. of lanes } & 1 entry lane \\
\hline & & 1 exit lane \\
\hline & Lane width & $3.00 \mathrm{~m}$ \\
\hline & Grade & $0 \%$ \\
\hline & Separate left/right turn lanes & None \\
\hline & Parking provisions & None \\
\hline \multirow{6}{*}{ Approach 3 - W } & \multirow{2}{*}{ No. of lanes } & 2 entry lanes \\
\hline & & 1 exit lane \\
\hline & Lane width (m) & $3.00 \mathrm{~m}$ \\
\hline & Grade $(\%)$ & $0 \%$ \\
\hline & Separate left/right turn lanes & Separate left turn lane \\
\hline & Parking provisions & None \\
\hline \multirow{6}{*}{ Approach 4 - N } & \multirow{2}{*}{ No of lanes } & 2 entry lanes \\
\hline & & 1 exit lane \\
\hline & Lane width (m) & $3.00 \mathrm{~m}$ \\
\hline & Grade & $0 \%$ \\
\hline & Separate left/right turn lanes & Separate left turn lane \\
\hline & Parking provisions & None \\
\hline
\end{tabular}

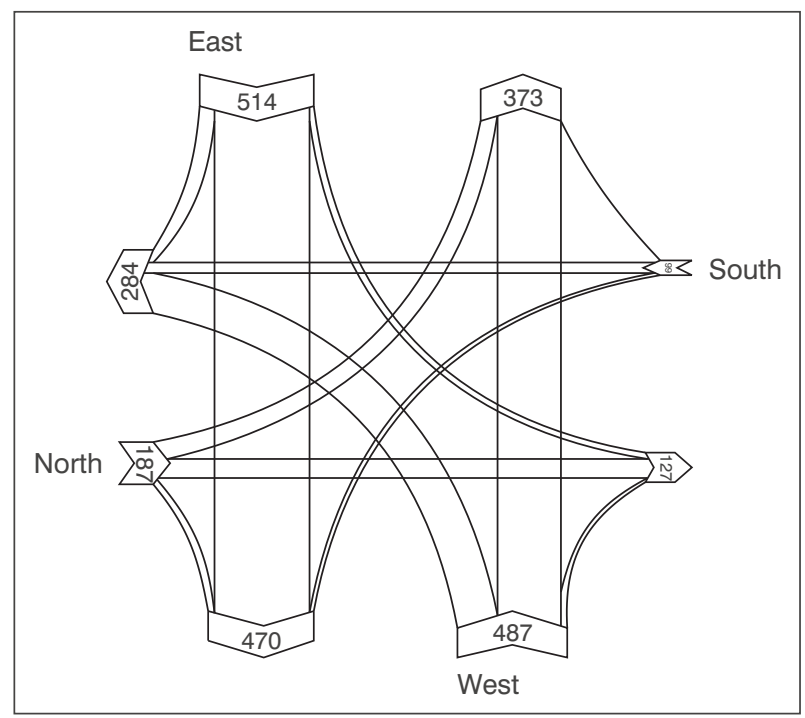

Figure 3 - Peak hour traffic demand flows ratio is the main prerequisite for developing and implementing the semi-actuated traffic signal control which would provide unconditional priority to the major flow.

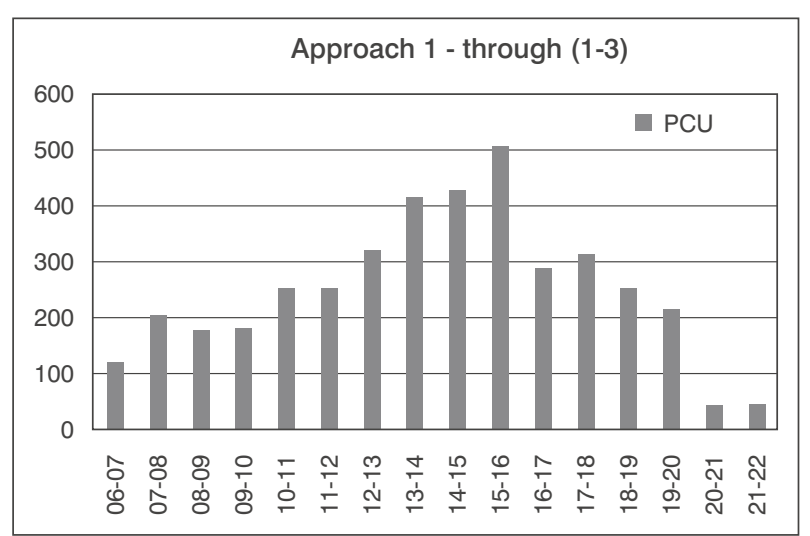

Figure 4 - Major Traffic flow 


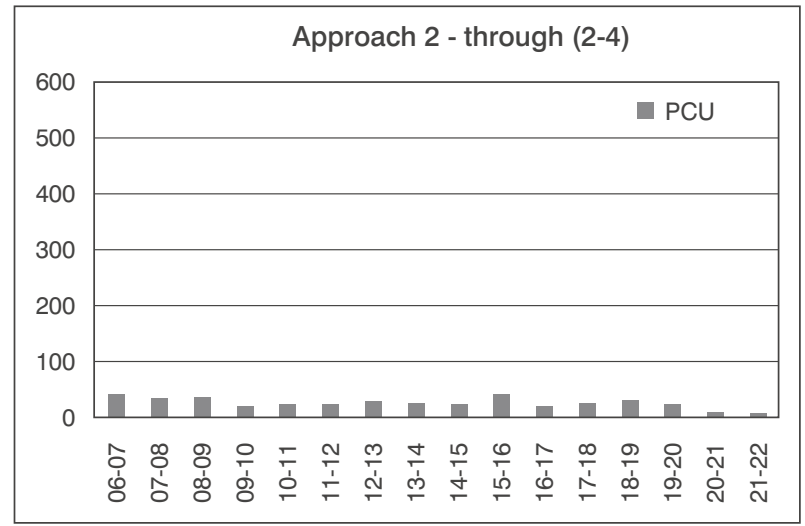

Figure 5 - Minor Traffic Flow

The indicator for the intersection performance was the vehicle delays ${ }^{3}$ at the approaches and the level of service (LOS).

VISSIM is able to calculate the delay per vehicle between two user-defined points. The delay within VISSIM is defined as the average total delay per vehicle in seconds. The total delay is calculated by subtracting the theoretical (ideal travel time) from the real travel time. The theoretical time is the time that it would take to travel between two points if there were no other vehicles and no signal controls within the network.

After the simulation of the above stated two-phase and pre-timed controlled intersection, the following parameters for the operational performance were obtained (Table 3).

The analysis of the simulation results has led to the following observations:

1. The largest delays appear at the major street (Approaches 1 and 3 ). The $\mathrm{LOS}=\mathrm{C}$;
2. The minor flow appears to be interesting. For both approaches ( 2 and 4$), \mathrm{LOS}=\mathrm{A}$. This is due to the low vehicle flows. During the simulation process, a state where no vehicles during the green intervals were perceived. (Especially on Approach 2);

3. The general performance is not poor (overall $\mathrm{LOS}=$ C);

4. If semi-actuated control is going to be implemented, before-and-after intersection operational analysis has to be made. The outcome results concerning the time losses (delays) will be worthy of note.

\section{DESIGNING SEMI-ACTUATED TRAFFIC SIGNAL CONTROL ALGORITHM}

\subsection{Definition of semi-actuated control model conditions and parameters}

The model parameters must be set first: minimum green, maximum green, the yellow and all red time as well as the green extension unit. The traffic conditions to be set concern the green interval termination or its extension on the basis of the vehicle time headways. The data on the number of accumulating vehicles during the red time, and the data on the number of dispersing vehicles during the green time within the cycle were collected.

On the basis of traffic flow conditions in the state of saturation ${ }^{4}$ the following model parameters were determined:

Table 3 - Simulation results (Pre-timed signal control)

\begin{tabular}{|c|c|c|c|c|c|}
\hline & $\begin{array}{l}\text { Movement/ } \\
\text { Approach }\end{array}$ & $\begin{array}{c}\text { Delay } \\
(\mathrm{sec})\end{array}$ & $\begin{array}{c}\text { Level of Service } \\
\left(\mathrm{LOS}^{*}\right)\end{array}$ & $\begin{array}{l}\text { Level of Service } \\
\text { (LOS) /approach }\end{array}$ & $\begin{array}{c}\text { Overall Level of } \\
\text { Service (LOS) }\end{array}$ \\
\hline \multirow{3}{*}{$\begin{array}{l}\text { Approach } 1 \\
\text { (major flow) }\end{array}$} & $\mathrm{W}-\mathrm{N}$ & 35.6 & $\mathrm{D}$ & \multirow{3}{*}{$\begin{array}{c}32.8 \mathrm{sec} \\
\mathrm{LOS}=\mathrm{C}\end{array}$} & \multirow{12}{*}{$\begin{array}{l}27.7 \mathrm{sec} \\
\mathrm{LOS}=\mathrm{C}\end{array}$} \\
\hline & W-E & 35.2 & $\mathrm{D}$ & & \\
\hline & $\mathrm{W}-\mathrm{S}$ & 23.3 & $\mathrm{C}$ & & \\
\hline \multirow{3}{*}{$\begin{array}{l}\text { Approach } 2 \\
\text { (minor flow) }\end{array}$} & $\mathrm{N}-\mathrm{E}$ & 1.7 & A & \multirow{3}{*}{$\begin{array}{l}3.59 \mathrm{sec} \\
\mathrm{LOS}=\mathrm{A}\end{array}$} & \\
\hline & $\mathrm{N}-\mathrm{W}$ & 2.9 & A & & \\
\hline & $\mathrm{N}-\mathrm{S}$ & 4.0 & A & & \\
\hline \multirow{3}{*}{$\begin{array}{l}\text { Approach } 3 \\
\text { (major flow) }\end{array}$} & $E-W$ & 35.8 & $\mathrm{D}$ & \multirow{3}{*}{$\begin{array}{l}34.8 \mathrm{sec} \\
\mathrm{LOS}=\mathrm{C}\end{array}$} & \\
\hline & $\mathrm{E}-\mathrm{N}$ & 15.0 & $\mathrm{~B}$ & & \\
\hline & $E-S$ & 26.5 & $\mathrm{C}$ & & \\
\hline \multirow{3}{*}{$\begin{array}{l}\text { Approach } 4 \\
\text { (minor flow) }\end{array}$} & $S-W$ & 6.6 & A & \multirow{3}{*}{$\begin{array}{l}3.18 \mathrm{sec} \\
\mathrm{LOS}=\mathrm{A}\end{array}$} & \\
\hline & $\mathrm{S}-\mathrm{E}$ & 0.2 & A & & \\
\hline & $\mathrm{S}-\mathrm{N}$ & 3.4 & A & & \\
\hline
\end{tabular}

*According to HCM 2000 
1) the value of saturated time headway amounts to 1.7 seconds,

2) the value of the maximum time headway amounts to 2.0 seconds (limits range from 1.7 to $1.9 \mathrm{sec}$ onds),

3) the vehicle speed is defined in the VISSIM network in the range of 30 to $35 \mathrm{~km} /$ hour (for PC) and of 30 to $25 \mathrm{~km} /$ hour (for HGV and BUS) (with the speed limit of $50 \mathrm{~km} /$ hour in urban areas),

4) the non-occupancy inductive loop time (no vehicles present) is equivalent to the desired maximum time headway. For time headway of two seconds, the time of the non-occupancy inductive loop time is one second. This is the time needed for determination of the green extension unit.
With such parameters set, the condition for green extension time was determined: if the non-occupancy inductive loop time is longer than one second, then the phase ends with minimum green time (there is no green extension). If it is less than one second, then the green will be extended for two seconds.

\subsection{Design of semi-actuated signal control logic}

The suggested actuated controller has been designed to work in four phases with allowed left turns and a double barrier. The working principle is the same as in NEMA controllers. According to the condi-

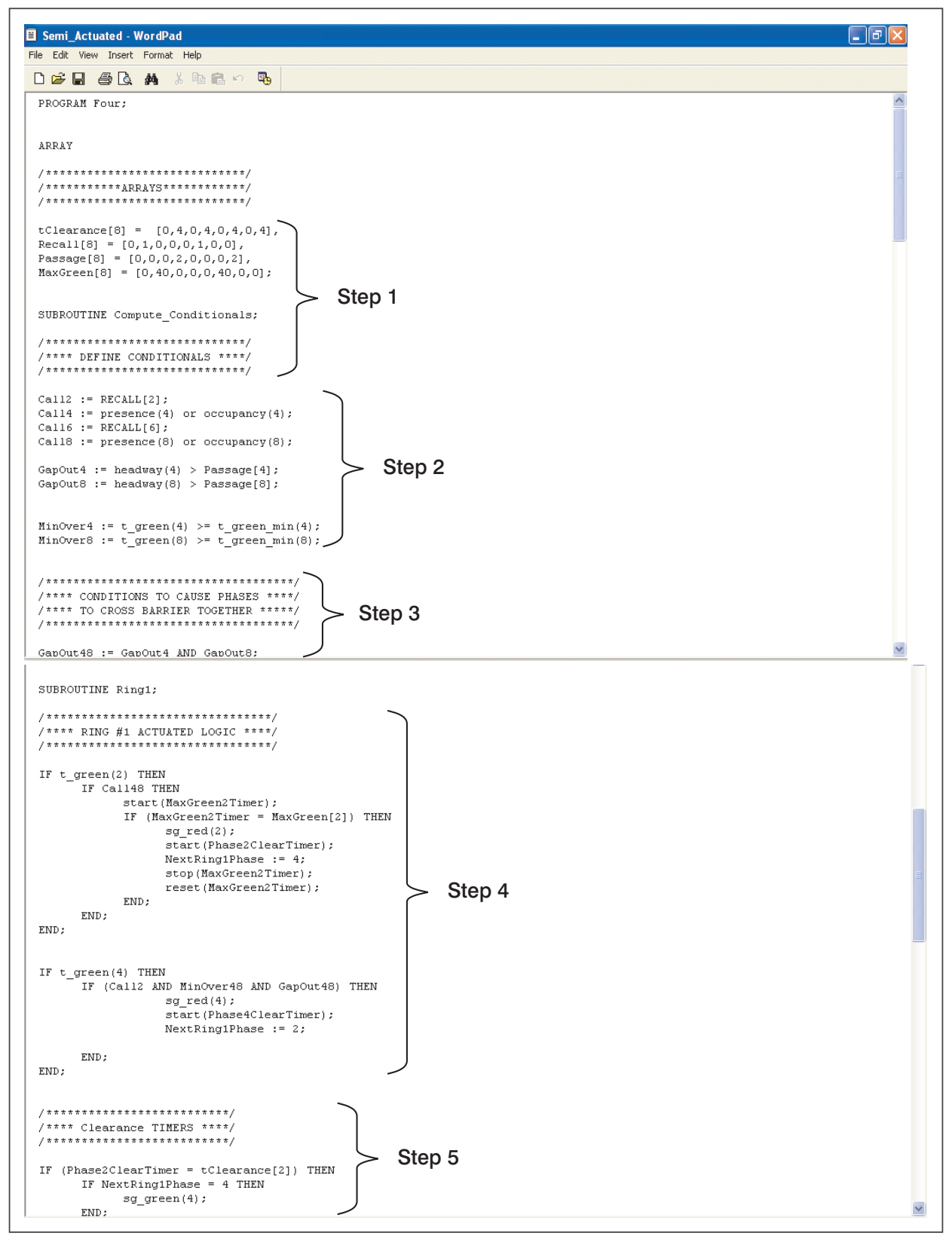

Figure 7 - Design of signal control logic in VAP 
tions and parameters already set, signal timing design was performed with VAP.

The phase development order is shown in Figure 6.

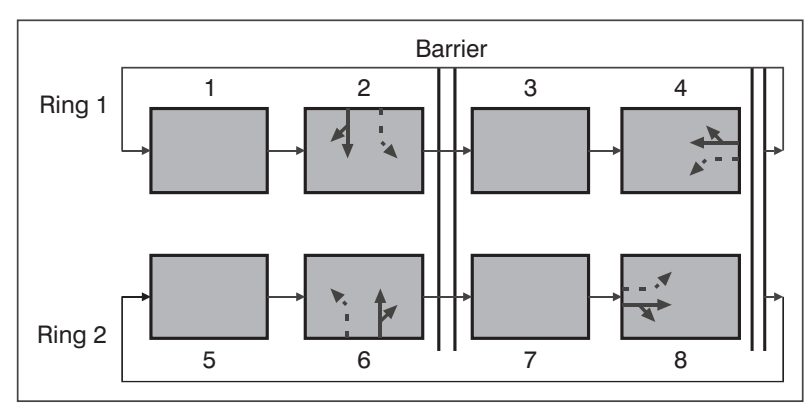

Figure 6 - Phase diagram of

semi-actuated signal control

Within the order defined, the traffic signals operate in the following way: if on the major approach the signal is green and if there is a call on the minor approach, then the counting down for the maximum green time on the major approach starts. When the given value has been achieved, the green time is provided for/switched to the minor approach. If the non-occupancy inductive loop time on the minor approach is longer than the given extension unit (time of passage), then the green time is terminated and switched to the major approach. The model design is performed through the following steps (Figure 7):

Step 1: Defining of the constants;

Step 2: Defining of the conditions;

Step 3: Defining of the phase demands/barriers;

Step 4: Designing of the signal logic (Ring 1 and Ring 2);

Step 5: Defining of the yellow and all red time (clearance time logic) for each ring.

\subsection{Implementation of the algorithm and inductive loops in the VISSIM network}

After the model has been designed, two scenarios of the inductive loop placement in VAP were developed. The following time parameters were taken up:

\section{Scenario 1:}

\section{Placing of the inductive loop at the STOP line}

$\begin{array}{ll}\begin{array}{l}\text { Minimum green } \\ \text { Time extension unit }\end{array} & \begin{array}{l}5 \text { seconds, } \\ \text { Maximum green }\end{array} \\ \begin{array}{l}\text { The yellow and } \\ \text { The all red time }\end{array} & 4 \text { seconds }- \text { major approach, }\end{array}$

Scenario 2:

Placing of the inductive loop at 8 metres from the STOP line $\begin{array}{ll}\text { Minimum green } & 8 \text { seconds, } \\ \text { Time extension unit } & 2 \text { seconds, } \\ \text { Maximum green } & 40 \text { seconds - major approach, }\end{array}$

The yellow and

the all red time 4 seconds.

Different inductive loop detector placements require different time parameters. The minimum green time and the time extension unit increase when the inductive loop is placed at a longer distance from the stop line. The maximum green time values on the major approach can vary in the range from 40 to $60 \mathrm{sec}$ onds 5 .

\subsection{Discussion}

After the simulation has been performed, the Delays and the Level of Service (LOS) for all the approaches and directions of movement were calculated (Table 4).

For Scenario 2 (the inductive loop is placed at a distance of 8 metres from the STOP line), the output results (delays and LOS) are shown in Table 5.

A comparison analysis of intersection performance for both types of signal control strategies (pre-timed vs. semi-actuated control) is shown in Table 6 .

The before-and-after intersection performance analysis has led to the following observations:

A) Scenario 1 (the inductive loop detector is placed at the stop line):

- Major flow delays have been reduced by $30 \%$ vs. current state.

- The Level of Service has decreased by one level down on the minor flow approaches (from $\mathrm{LOS}=\mathrm{A}$ to $\mathrm{LOS}=\mathrm{B})$.

B) Scenario 2 (the inductive loop is placed at 8 metres from the Stop line):

- Delays on both major and minor flows have been reduced by $15 \%$ and $12 \%$, respectively. The major flow delay reduction proves that the green interval length is not always a parameter to rely on in order to increase the LOS of that approach.

- Minor flow delays have been reduced by $13 \%$ and $23 \%$ on both approaches $(2,4)$ This is due to the fact that the controller has the information on the queue length (there is no information on the vehicles behind the loop), which is of utmost importance for the green time distribution on the minor approach.

- The overall LOS is B. It has been improved by one level up as compared with the current state.

As compared with the current state, the overall delay reduction for Scenario 1 is $17 \%$ and $32 \%$ for Scenario 2 . The reduction of delays for changed detector 
Table 4 - Output results, Scenario 1

\begin{tabular}{|c|c|c|c|c|}
\hline \multicolumn{5}{|c|}{ Scenario 1} \\
\hline \multicolumn{2}{|l|}{ Placement } & \multicolumn{3}{|l|}{ At the stop line } \\
\hline \multicolumn{2}{|l|}{ Minimum green } & \multicolumn{3}{|l|}{5 seconds } \\
\hline \multicolumn{2}{|c|}{ Time extension unit } & \multicolumn{3}{|l|}{1 second } \\
\hline \multicolumn{2}{|l|}{ Maximum green } & \multicolumn{3}{|l|}{50 seconds } \\
\hline \multicolumn{2}{|c|}{ Yellow and all red time } & \multicolumn{3}{|l|}{4 seconds } \\
\hline & & Delays/Approach (sec) & LOS/Approach & Overall LOS \\
\hline \multirow{3}{*}{$\begin{array}{l}\text { Approach I } \\
\text { (major flow) }\end{array}$} & $\mathrm{W}-\mathrm{N}$ & 27.6 & \multirow{3}{*}{$\begin{array}{l}25.2 \mathrm{sec} \\
\mathrm{LOS}=\mathrm{C}\end{array}$} & \multirow{12}{*}{$\begin{array}{c}23 \mathrm{sec} \\
\mathrm{LOS}=\mathrm{B}\end{array}$} \\
\hline & $\mathrm{W}-\mathrm{E}$ & 21.5 & & \\
\hline & $\mathrm{W}-\mathrm{S}$ & 17.3 & & \\
\hline \multirow{3}{*}{$\begin{array}{l}\text { Approach } 2 \\
\text { (minor flow) }\end{array}$} & $N-E$ & 10,6 & \multirow{3}{*}{$\begin{array}{l}10.1 \mathrm{sec} \\
\mathrm{LOS}=\mathrm{B}\end{array}$} & \\
\hline & $\mathrm{N}-\mathrm{W}$ & 10.2 & & \\
\hline & $\mathrm{N}-\mathrm{S}$ & 11.4 & & \\
\hline \multirow{3}{*}{$\begin{array}{l}\text { Appoach } 3 \\
\text { (major flow) }\end{array}$} & $E-W$ & 27.6 & \multirow{3}{*}{$\begin{array}{l}23.7 \mathrm{sec} \\
\mathrm{LOS}=\mathrm{C}\end{array}$} & \\
\hline & $E-S$ & 16.3 & & \\
\hline & $E-S$ & 25.2 & & \\
\hline \multirow{3}{*}{$\begin{array}{l}\text { Approach } 4 \\
\text { (minor flow) }\end{array}$} & $\mathrm{S}-\mathrm{W}$ & 10.7 & \multirow{3}{*}{$\begin{array}{l}11.15 \mathrm{sec} \\
\mathrm{LOS}=\mathrm{B}\end{array}$} & \\
\hline & $S-E$ & 13.0 & & \\
\hline & $S-N$ & 14.8 & & \\
\hline
\end{tabular}

Table 5 - Output results, Scenario 2

\begin{tabular}{|c|c|c|c|c|}
\hline \multicolumn{5}{|c|}{ Scenario 2} \\
\hline \multicolumn{2}{|l|}{ Placement } & \multicolumn{3}{|l|}{8 metres from the stop line } \\
\hline \multicolumn{2}{|l|}{ Minimum green } & \multicolumn{3}{|l|}{8 seconds } \\
\hline \multicolumn{2}{|c|}{ Time extension unit } & \multicolumn{3}{|l|}{2 seconds } \\
\hline \multicolumn{2}{|l|}{ Maximum green } & \multicolumn{3}{|c|}{40 seconds - major approach } \\
\hline \multirow{2}{*}{\multicolumn{2}{|c|}{ Yellow and all red time }} & \multicolumn{3}{|l|}{4 seconds } \\
\hline & & Delays/Approach (sec) & LOS/Approach & Overall LOS \\
\hline \multirow{3}{*}{$\begin{array}{l}\text { Approach I } \\
\text { (major flow) }\end{array}$} & $\mathrm{W}-\mathrm{N}$ & 22.6 & \multirow{3}{*}{$\begin{array}{l}21.9 \mathrm{sec} \\
\mathrm{LOS}=\mathrm{C}\end{array}$} & \multirow{12}{*}{$\begin{array}{c}19 \mathrm{sec} \\
\mathrm{LOS}=\mathrm{B}\end{array}$} \\
\hline & $\mathrm{W}-\mathrm{E}$ & 20.7 & & \\
\hline & $\mathrm{W}-\mathrm{S}$ & 13.3 & & \\
\hline \multirow{3}{*}{$\begin{array}{l}\text { Approach } 2 \\
\text { (minor flow) }\end{array}$} & $\mathrm{N}-\mathrm{E}$ & 7.7 & \multirow{3}{*}{$\begin{array}{c}8.9 \mathrm{sec} \\
\mathrm{LOS}=\mathrm{A}\end{array}$} & \\
\hline & $\mathrm{N}-\mathrm{W}$ & 10.1 & & \\
\hline & $\mathrm{N}-\mathrm{S}$ & 11.8 & & \\
\hline \multirow{3}{*}{$\begin{array}{l}\text { Approach } 3 \\
\text { (major flow) }\end{array}$} & $\mathrm{E}-\mathrm{W}$ & 23.4 & \multirow{3}{*}{$\begin{array}{l}21.2 \mathrm{sec} \\
\mathrm{LOS}=\mathrm{C}\end{array}$} & \\
\hline & $\mathrm{E}-\mathrm{N}$ & 9.4 & & \\
\hline & $\mathrm{E}-\mathrm{S}$ & 18.75 & & \\
\hline \multirow{3}{*}{$\begin{array}{l}\text { Approach } 4 \\
\text { (minor flow) }\end{array}$} & $\mathrm{S}-\mathrm{W}$ & 8.6 & \multirow{3}{*}{$\begin{array}{c}9.3 \mathrm{sec} \\
\mathrm{LOS}=\mathrm{A}\end{array}$} & \\
\hline & $S-E$ & 8.9 & & \\
\hline & $\mathrm{S}-\mathrm{N}$ & 10.14 & & \\
\hline
\end{tabular}


Table 6 - Before-and-after analysis of intersection performance

\begin{tabular}{|c|c|c|c|}
\hline \multirow{2}{*}{ Approach } & \multicolumn{3}{|c|}{ Delays (s) } \\
\hline & Current State (s) & Scenario $1(\mathrm{~s})$ & Scenario $2(\mathrm{~s})$ \\
\hline Approach 1 & 32.8 & 25.2 & 21.9 \\
\hline Approach 2 & 3.59 & 10.1 & 8.9 \\
\hline Approach 3 & 34.8 & 23.7 & 21.2 \\
\hline Approach 4 & 3.18 & 11.15 & 9.3 \\
\hline All & 27.7 & 23 & 19 \\
\hline \multicolumn{4}{|c|}{ Delays ratio $(\%)$} \\
\hline Approach & & Scenario 1 vs. Current state & Scenario 2 vs. Scenario 1 \\
\hline Approach 1 & & -33 & 15 \\
\hline Approach 2 & & 135 & 13 \\
\hline Approach 3 & & -32 & 12 \\
\hline Approach 4 & & 127 & 23 \\
\hline \multicolumn{4}{|c|}{ Overall LOS } \\
\hline & Current State & Scenario 1 & Scenario 2 \\
\hline & $\mathrm{LOS}=\mathrm{C}$ & $\mathrm{LOS}=\mathrm{B}$ & $\mathrm{LOS}=\mathrm{B}$ \\
\hline
\end{tabular}

placements (Scenario 2 vs. Scenario 1) is $18 \%$. The LOS for both scenarios is B (one level higher as compared to the current state).

This analysis has proved that the inductive loop placement has an impact on delays. By increasing the inductive loop distance from the stop line, the LOS improves. With regard to the question whether any intersection operational performance improvement can be expected by further increase of the inductive loop distance from the stop line, the answer will be probably positive. The improvement of the LOS would be insignificant because of the intersection geometry and the major vs. minor flows ratio.

By appropriate inductive loop detector placement in the relation to the stop line and in an interaction with the signal time parameters, the overall intersection performance could be improved (reduction of the delays, LOS increase) but only if the limitation conditions concerning inductive loop placements are taken into consideration. However, the signal time parameters are to be of crucial importance.

\section{CONCLUSION}

In case of large traffic flows misbalances (major vs. minor flow), the implementation of a semi-actuated traffic signal control is recommended as good substitution for the conventional pre-timed signal control. The effect of the inductive loop detector placement in relation to the STOP line on the overall intersection performance is being emphasized as of great significance. Therefore, by designing two scenarios for in- ductive loop detector placement, and with the semi-actuated control algorithm developed and applied in VISSIM, it has been proved that the inductive loop detector placement has an impact on the overall Level of Service (LOS) of the intersection through the delays foreseen.

There are the possibilities for developing new scenarios but they could make the model more complex particularly when modeling the discharge of the minor flow. In relation to the inductive loop placement, this possibility is reduced. Summarizing, adequate placement of the inductive loop detector in relation to the STOP line and in an interaction with the signal time parameters results in an improvement of the overall intersection performance (reduction of the delays, LOS increase). Hence, the detector placement distances have to be considered under the limitation conditions only.

The future developments go in the direction of area detection or as recently published, in lane-to-lane detection. The adaptive control signal strategy is being assumed as of the latest achievements in advanced traffic signal control strategies.

For the Republic of Macedonia, the implementation of advanced traffic signal control strategies will entail the development of equipment and standardization. Criteria have to be defined for putting the systems into operation. It is recommended that:

1) the philosophy of traffic signal control strategies design is to be changed and adjusted as well,

2) standards for new technologies have to be introduced, 
3) scientific and research work on the development îf simulation models has to be intensified,

4) financing has to be safe and sound.

\section{М-р ДАНИЕЛА КОЛТОВСКА НЕЧОСКА}

Е-пошта: daniela.koltovska@uklo.edu.mk Универзитет „Св. Климент Охридски“, Технички факултет П. Фах 99, 7000 Битола, Република Македонија

\section{Д-р КРИСТИ М. БОМБОЛ}

Е-пошта: kristi.bombol@uklo.edu.mk

Универзитет „Св. Климент Охридски“, Технички факултет П. Фах 99, 7000 Битола, Република Македонија

\section{АПСТРАКТ}

\section{ВЛИЈАНИЕ НА РАСТОЈАНИЕТО НА ПОСТА- ВУВАҢЕ НА ДЕТЕКТОРОТ ВРЗ РАБОТАТА НА СИГНАЛИЗИРАНА КРСТОСНИЦА}

Си уште постојат земји (како Република Македонија) каде ито во управувањето и контролата на сообракајот се применуваат само традионалните системи. И покрај флуктуачиите во токовите и зголемената сообракајна побарувачка во изминатите 15 години во градовите во Македонија, си уште се користат системите за фиксна контрола на сообраќајот. Ова предизвикува проблеми на сообраќајната мрежа (зголемени времиьа на патување, зголемени трошочи на патување и деградаиија на животната средина). Очигледен е повикот дека ,, нешто треба да се направи “. Најдобрите практики покажуваат дека тоа може да се реализира со примена на неконвенционалните решенија т. е со примена на системите што се зависни од сообраќајот. Многу разумен пример на таков систем е поттикнатата сообраќајна сигнална контрола, предизвк со којшто ние се соочивме.

Оттука во истражувањето исправени бевме пред две барања. Како прво, научно да докажеме дека поттикнатата сообраќајна сигнална контрола навистина може да биде реална замена за фиксната контрола со што ке се зголеми вкупната ефикасност на сигнализираната кртоснииа, но со правилно проектирани временски параметри и локаиија на детекторот. Како второ, да се покаже дека ваквиот напреден систем за контрола е можен и одржлив за македонските градови. Овој труд се фокусира на првоmо барање.

Во таа насока проектирана е полупоттикната сообраќајна сигнална стратегија на соодветно избрана индивидуална крстосница. Основната иел беше да се одреди на кој начин поставуването на детекторската индуктивна јамка во однос на СТОП линијата влије врз севкупната работа на крстосницата. За да се оствари целта, проектирани беа две сиенарија: 1. Поставуване на детекторот на СТОП линијата и 2. Поставуване на детекторот на 8 м од СТОП линијата. Посебен акиент е ставен на проектирање на алгоритмот на полупоттикнатата сигнална контрола. Проектираниот алгоритам е применет во мрежата на VISSIM со иел да се симулира прочесот на полупоттикната сообраќајна сигнална контрола. Направена е споредбена анализа на ефикасноста на крстосницата (пред и потоа). Се заклучи дека со соодветно поставување на детекторот и во интеракиија со сигналните параметри, може да се подобри севкупната работа на крстосницата, но само при одредени ограничувачки фактори за растојанијата на поставуване.

\section{КЛУЧНИ ЗБОРОВИ}

индивидуална сигнализирана крстосница, поттикната сигнална контрола, полупоттикната сигнална контрола, детектори на индуктивна јамка, симулација, временски загуби, ниво на услуга

\section{REFERENCES}

1. Testing Innovative Strategies For Clean Urban Transport For Historic European Cities - RENAISSANCE (FP7 Project, 2008- 2012)

2. McShane. W. R., Roess, P. R., Prassas, S. E., Traffic Engineering, Prentice Hall, Upper Saddle River, New Jersey 07458,1998 , pp 542-545

3. VISSIM 4.20 User Manual, PTV Planung Transport Verkehr AG, 2006 pp 250

4. Kyte. M., Wang. H., Effect of detector And Timing Parameters on Operations of Cross Street of Isolated Intersection, Idaho, 2007

5. Basic Signal Timing Controller Parameters, UIdaho, 2007

\section{LITERATURE}

[1] Button, K. J., Hensher, D. A.: Handbook of Transport Systems and Traffic Control, Netherlands, 2001

[2] McShane, W., et al.: Traffic Engineering, New Jersey, 1998

[3] Traffic Control Systems Handbook, US Department of Transport, Federal Highway Administration, February, 1996

[4] Колтовска, Д., Проценка на ефикаснота на работа на изолирана крстосница со поттикната сообраќајна сигнална контрола, Магистерски труд, УКЛО, Битола, Република Македонија, 2008

[4] Akcelik, R.: Signal Timing Analysis for Vehicle Actuated Control“", Working Paper WD TE 95/007, ARRB, Transport Research Ltd, Australia

[5] Akcelik, R.: Analysis of vehicle-actuated signal operations", Australian Road Research Board, Working Paper WD TE 93/007, 1993

[6] Bombol, K. M., Modern Requirements of Traffic Flow Control Systems - Current Development. Proceedings, ISEP 97, Elektrotehni $1 \frac{2 k a}{2}$ Zveza Slovenije, Ljubljana, Slovenija, 1997, pp 261-264

[7] Courage, G., Papanou, P.: Estimation Delay at Traffic-actuated Signals, Transportation Research Record, 630, pp $17-21$

[8] Kyte, M., Wang, H.: Effect of detector and Timing Parameters on Operations of Cross Street of Isolated Intersection, U Idaho, 2007

[9] Luttenen T. R., Nevala. R.: Capacity and Level of Service of Finnish signalized Intersections, Finnra Reports 25/2002, Helsinki 
[10] Al-Mudhaffar, A.: Impacts of Traffic Signal Control Strategies, Doctoral Thesis in Traffic and Transport Planning, Infrastructure and Planning Royal Institute of Technology, Stockholm, Sweden 2006, pp 5- 6

[11] Testing Innovative Strategies For Clean Urban Transport For Historic European Cities RENAISSANCE (FP 7 Project, 2008- 2012)
[12] Robertson, H., et al.: Actuated signals and detection, Manual of Guidance, Vol. 3, 1994, No. 2

[13] Basic signal timing controller parameters, UIdaho, 2007.

[14] Traffic Signals - Section IV, Engineering Concepts / Guidelines, UIdaho

[15] Highway Capacity Manual, 2000

[16] PTV VISSION, VISSIM 4.2, USER MANUAL

[17] VAP MANUAL 